\title{
HRJ
}

V.2 n.12 (2021)

Recebido: 05/01/2021

Aceito: 06/07/2021

\section{Diagnostic and therapeutic approach to esthesioneuroblastoma: a case report}

\author{
Isabela Porto Silva Costa ${ }^{1}$ \\ Talita Trindade França ${ }^{2}$ \\ Ivelise Theresa Araujo Balby ${ }^{3}$ \\ Gustavo Henrique Campos de $\operatorname{Sousa}^{4}$ \\ Luis Alves de Pinho Segundo ${ }^{5}$
}

\author{
${ }^{1}$ Hospital de Base do Distrito Federal - ORCID 0000-0001-9357-5361 \\ ${ }^{2}$ Centro Universitário de Brasília - ORCID 0000-0001-5374-6875 \\ ${ }^{3}$ Hospital de Base do Distrito Federal - ORCID 0000-0001-7582-8214 \\ ${ }^{4}$ Hospital de Base do Distrito Federal - ORCID 0000-0002-6694-4595 \\ ${ }^{5}$ Hospital de Base do Distrito Federal - ORCID 0000-0001-5986-6712
}

\begin{abstract}
Esthesioneuroblastoma is a rare neoplasm of the nervous system that appears in the paranasal cavities derived from the olfactory neuroepithelium. Kadish classification is the most widely used to stage it according to its extension. The symptomatology is unspecific, and it may present progressive unilateral nasal obstruction, epistaxis, anosmia, headache, sinusitis, diplopia, and orbital proptosis. The diagnosis is based on the lesion biopsy, immunohistochemistry, and ultrastructural findings. Excision of the tumor is described as the treatment of choice that may be associated with radiotherapy and chemotherapy. This is a case report of an olfactory esthesioneuroblastoma in a patient admitted to the hospital complaining of orbital proptosis who, after a computed tomography of the skull, showed a suspicious lesion. After the biopsy and the anatomopathological study, a protocol with neoadjuvant chemotherapy was initiated, with the subsequent excision of the tumor. Despite the lack of other symptoms, an advanced stage of the neoplasm was identified, which reflects the importance of investigating less common complaints and thus facilitating the diagnosis and early treatment.
\end{abstract}

Keywords: olfactory neuroblastoma, esthesioneuroblastoma olfactory, head and neck neoplasms, paranasal sinus neoplasms, exophthalmos. 


\section{Abordagem diagnóstica e terapêutica do estesioneuroblastoma: um relato de caso}

\section{RESUMO}

Estesioneuroblastoma é uma neoplasia rara do sistema nervoso que surge nas cavidades paranasais derivadas do neuroepitélio olfativo. A classificação Kadish é a mais utilizada para estagiá-lo de acordo com sua extensão. A sintomatologia é inespecífica e pode apresentar-se com obstrução nasal unilateral progressiva, epistaxe, anosmia, dor de cabeça, sinusite, diplopia e proptose orbital. O diagnóstico é baseado na biópsia da lesão, na imuno-histoquímica e nos achados ultra-estruturais. A excisão do tumor é descrita como o tratamento de escolha, que pode estar associado à radioterapia e quimioterapia. Este é um relato de caso de estesioneuroblastoma olfatório em paciente admitido no hospital com queixa de proptose orbitária que, após tomografia computadorizada de crânio, evidenciou lesão suspeita. Após a biópsia e o estudo anatomopatológico, um protocolo com quimioterapia neoadjuvante foi iniciado, com a posterior excisão do tumor. Apesar da falta de outros sintomas, foi identificado um estágio avançado da neoplasia, o que reflete a importância de investigar as queixas menos comuns e, assim, facilitar o diagnóstico e o tratamento precoce.

Palavras-chave: neuroblastoma olfatório, estesioneuroblastoma olfatório, neoplasias de cabeça e pescoço, neoplasias do seio paranasal, exoftalmia.

\section{INTRODUCTION}

Esthesioneuroblastoma or olfactory neuroblastoma - a neoplasm of the sympathetic nervous system - is part of the main group of primitive neuroectodermal tumors (PNET) ${ }^{1}$ and a rare malignant tumor that appears in the paranasal cavities of the olfactory neuroepithelium, which is located in the cribriform region of the nasal fossa ${ }^{2}$. This tumor can invade the sinuses of the face, brain's base and orbital region ${ }^{1}$, and accounts for $4 \%$ to $6 \%$ of malignant sinus tumors $^{3,4}$. Esthesioneuroblastoma is different from other neuroblastic tumors because it occurs predominantly in adults, with a bimodal incidence in the second and fifth decades of life ${ }^{5}$, as well as a slight female predominance ${ }^{3}$.

This was first described in 1924 by Berger and $\mathrm{Luc}^{7}$ and classified in 1975 by Kadish in three stages, considering the extension of the injury ${ }^{8}$. The Classification of Kadish and the International TNM Classification of Malignant Tumors $^{9}$ are the most commonly used parameters to describe this tumor, although there are more recent proposals such as Dulguerov's $^{10}$, which is based on the extension of the tumor, Hyams ${ }^{11}$, which is based on 
histological criteria, and Biller's ${ }^{12}$, which takes into account the tumor size and presence of metastasis. Up to 1997, a total of 945 documented cases were reported, according to a study by Broich et $\mathrm{al}^{7}$.

The symptomatology is unspecific and it may present progressive unilateral nasal obstruction, nosebleeds, anosmia, headache and sinusitis. In some cases, diplopia and orbital proptosis are also observed ${ }^{3}$. Recognition of the tumor can be hampered by symptomatological features and should be considered as a differential diagnosis of nasal cavity diseases (nasal pilose, chronic rhinosinusitis, essential epistaxis or other malignant neoplasms $)^{13}$. The early diagnosis is key to guide the therapeutic choice according to its level of severity, aiming at the best possible prognosis for the patient.

\section{CASE REPORT}

A male patient, 44 years old, sought treatment in the Ophthalmology Department of the Instituto Hospital de Base do Distrito Federal for evaluation of orbital proptosis which started about one and a half years before. On skull magnetic resonance imaging (MRI), an expansive voluminous lesion, with a lobulated contour and intense contrast enhancement was identified, measuring about $8.3 \times 6.9 \times 6.4 \mathrm{~cm}$, the origin presumed to be from ethmoid sinuses. This lesion extended through the cribriform plate, cranial cavity, nasal cavities, orbits and nasopharynx. The anatomopathological study of the lesion found proliferation of small and hypercromatic cells (figure I), with Ki-67 proliferation marker positive in $30 \%$ of the cells of interest (figure II) and negative result for the smooth muscle actin (figure III) and CD34 (figure IV) tumor markers, compatible with neuroblastoma. The tumor was classified as Kadish stage C, Dulguerov stage T4, N0, Mx. After evaluating the result, chemotherapy (QT) was indicated for posterior surgical procedure. 


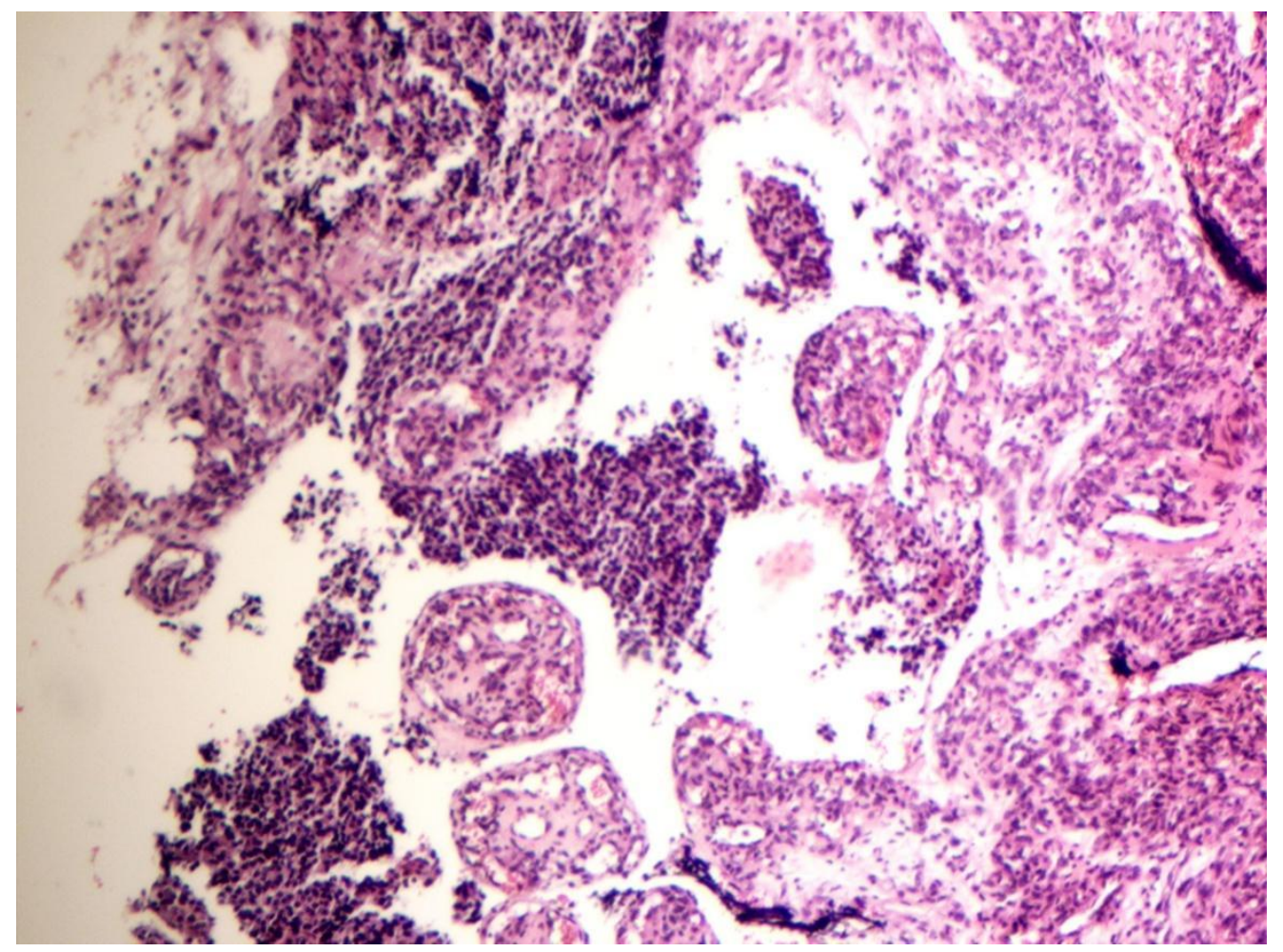

Figure I: Hematoxylin staining - presence of irregular islands of small, round and hyperchromatic cells, infiltrating vascularized connective tissue

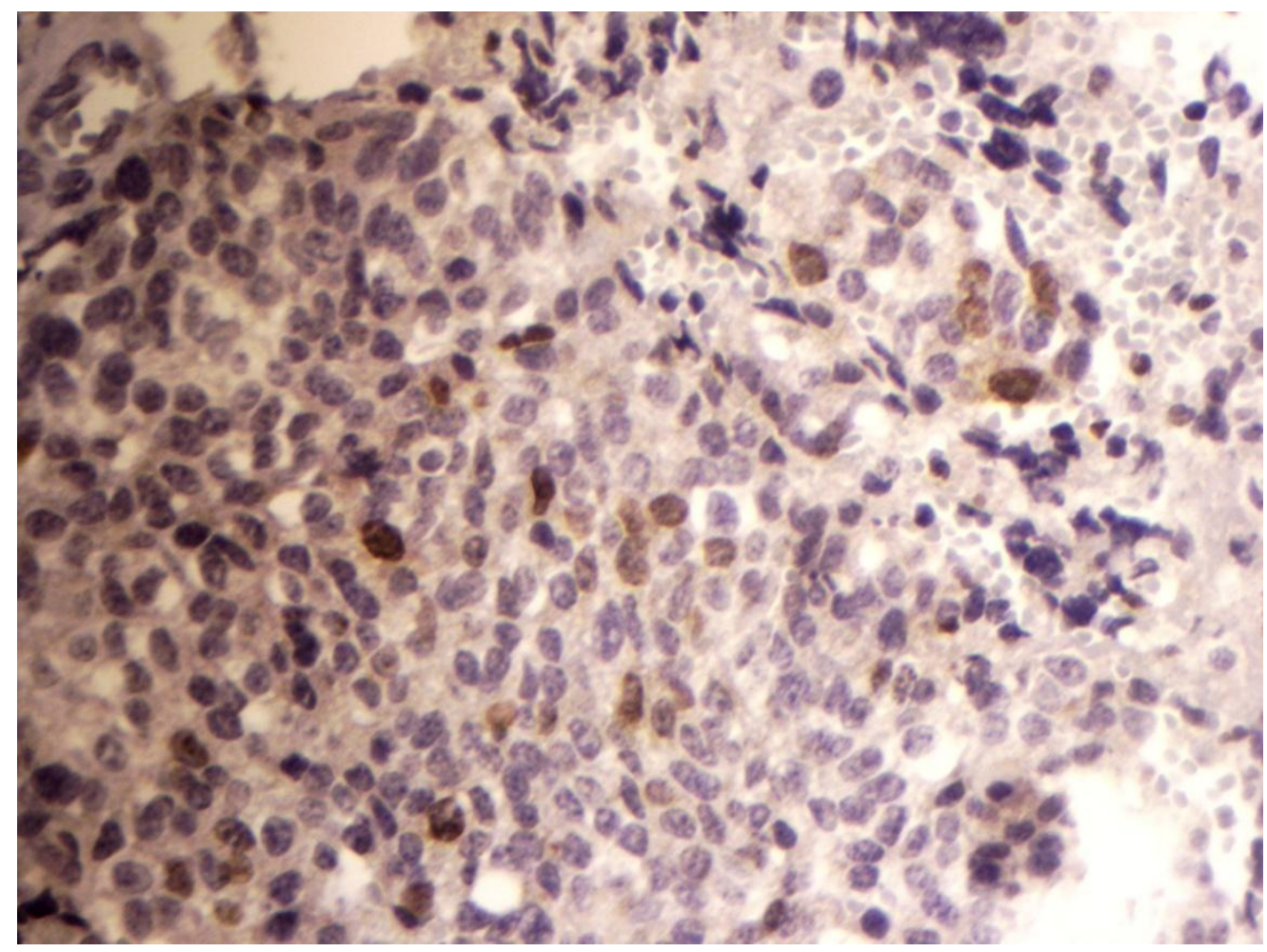

Figure II: Ki-67 proliferative marker - positive in $30 \%$ of cells of interest 


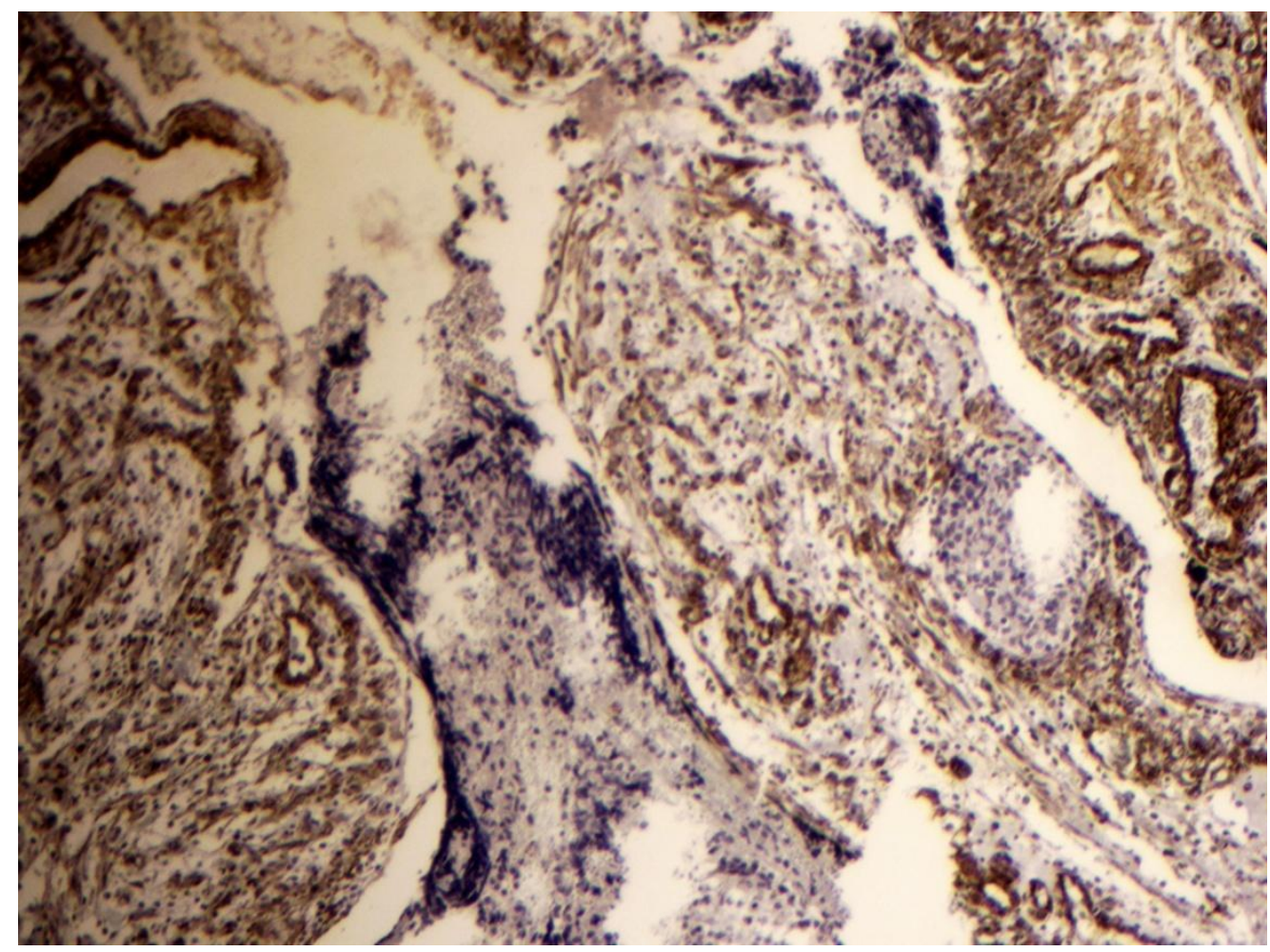

Figure III: Smooth muscle actin marker - negative in the cells of interest

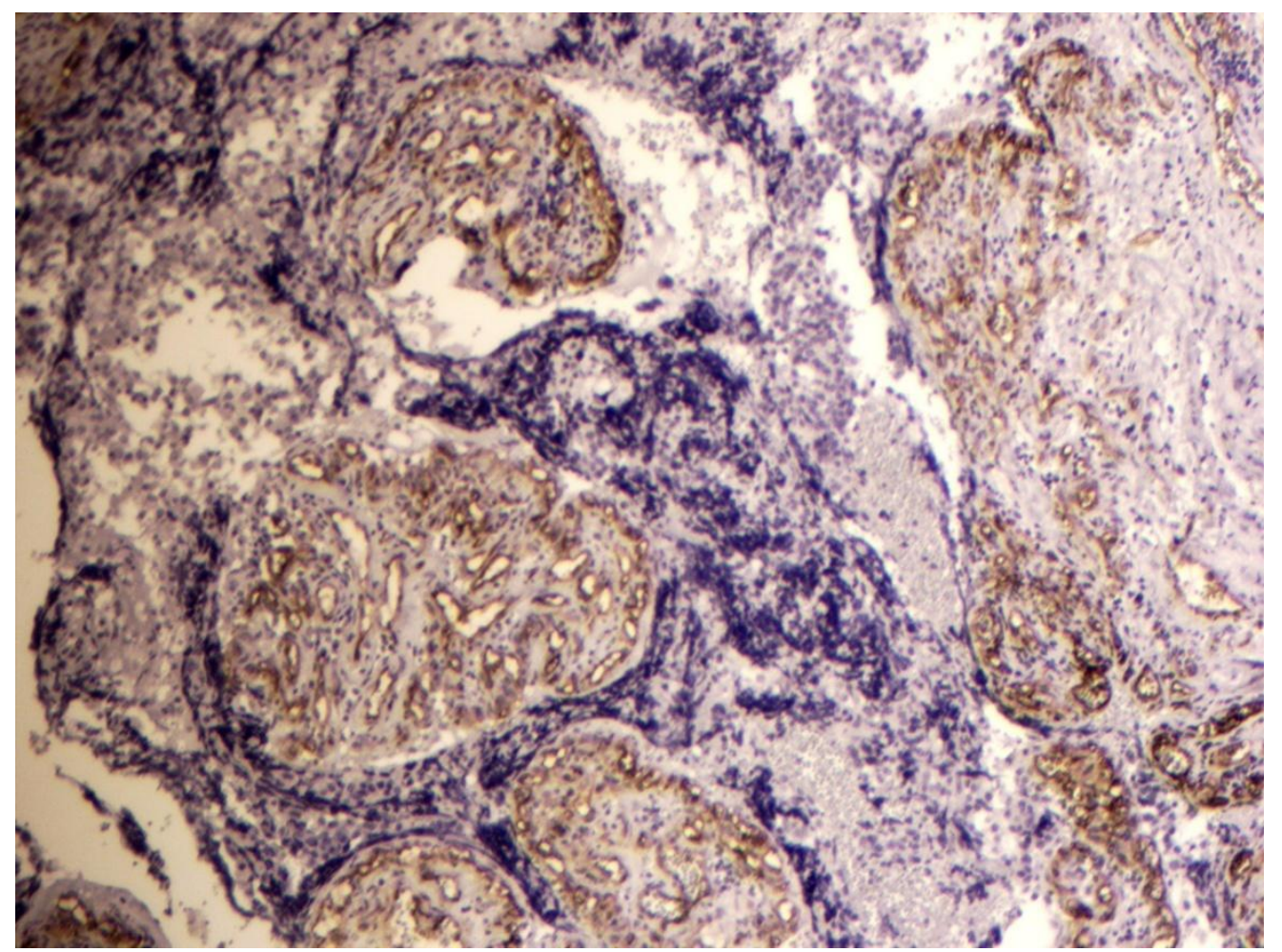

Figure IV: CD4 marker - negative in the cells of interest

After 15 days of the second chemotherapy dose, he was admitted to the Ophthalmology Emergency Room feeling pain and with purulent and fetid secretion from the 
right eye (RE). During ectoscopy he presented axial proptosis and lateral dystopia, lagophthalmos, edema on upper and lower eyelids at $3+/ 4+$, with hyperemia, local heat and stiffening on palpation. Visual acuity of the right eye without luminous perception and 20/25 vision in the left eye, with limited motricity in the contralateral eye and minimal amplitude. Intraorbital pressure was not feasible due to the apparent presence of fluid accumulation, without drainage. Biomycroscopy showed an irregular fotorreagent pupil, corneal melting and abundant mucopurulent secretion, chemosis at $3+/ 4+$, formed anterior chamber with absence of reaction, hypopyon or hyphema. Fundoscopy showing posterior pole of retina, papilledema at 5+/5+ with hyperemia, edema and ill-defined edges, physiological excavation, arch showing increased vessel caliber and macula without alterations. In the left eye, other parameters not significant.

Computed tomography (CT) of the orbits was requested and in addition to the voluminous lesion described at the previous MRI, a severe bilateral exophthalmos was observed, protruding to the right with secretion accumulation. The patient was hospitalized and began corticotherapy associated with topical antibiotic therapy and broad spectrum antibiotic therapy by oral route due to a possible presentation of extra nasal acute rhinosinusitis.

The therapeutic choice was made based on the advanced stage of the tumor, and right eye enucleation with neoadjuvant treatment was indicated. Five days after the surgical procedure, the situation regressed due to an episode of loss of consciousness that led the patient to fall and hit his head on the floor. After the episode, he presented disorganized speech and good movement execution. At non-contrast cranial CT, an apparent increase of the intracranial component of the probably expansive lesion that compromised the paranasal cavities and anterior cranial base was evidenced, determining an expansive effect on the 
adjacent cerebral parenchyma. Extensive vasogenic edema was noted in the frontobasal regions, causing an expansive effect characterized by erasure of the cortical sulci, compression of the lateral ventricles and deviation of the midline structures by up to $1 \mathrm{~cm}$ to the left, as well as subfalcine herniation. The hypothesis of an epileptic seizure associated with the evolution of the disease was raised, and dexamethasone and neurological surveillance being prescribed.

In a further evaluation, the patient condition evolved, there was hemodynamic stabilization, without episodes of fever or new epileptic seizures. He presented clinical and laboratory improvement, and chemotherapy-associated tubulopathy suggested symptoms of hypokalemia, hypomagnesemia and hypocalcemia. Thus, the chemotherapy was changed from Cisplatin to Carboplatin and neoadjuvant treatment continued in order to perform a further excision of the tumor.

\section{DISCUSSION}

The symptomatology of esthesioneuroblastoma is related to its mass tumor effect and varies according to its extension. At first sight, unspecific symptoms in the airways are common, and as a consequence other common diseases in this site may be speculated. In the report case, the mass effect initially presented only isolated orbital proptosis, as well as the patient delayed his search to the health service. This led to a late diagnosis with poor prognosis for the patient because when he arrived at the service he already presented an advanced stage of neoplasia. After the start of monitoring, he also presented symptoms of airways characteristic of this type of neoplasia.

With regard to the extension of the lesion, Kadish's classification was made from the study of 17 cases and determined as group A those tumors confined to nasal cavity, group B tumors involving sinuses and group $\mathrm{C}$ tumors spreading beyond the sinuses ${ }^{8}$. Seventeen years 
later, Dulguerov and Calcaterra classified these tumors as T1 for tumors restricted to the nasal cavity or sinuses without involving the sphenoid sinus or sphenoid cells, T2 for tumors reaching up to the cribriform plate, T3 for tumors reaching orbit or anterior cranial fossa, and T4 for tumors which extended to the brain ${ }^{10}$. An anatomical study of the extension is recommended along with imaging studies such as CT to check osteitis, skull base bone erosions and calcifications, as well as MRI to evaluate the existence of intracerebral and infraorbital invasion. These exams are also important to perform differential diagnosis with diseases that reach the nasal fossa roof such as meningoceles, meningoencephaloceles, polyps, inverted papillomas, nasosinus carcinomas, lymphoma, Edwig's sarcoma, melanoma, Merkel's carcinoma and others ${ }^{2}$. Invasion of the cribriform plate and paranasal sinuses is more common, while involvement of the anterior base of the skull, frontal and temporal lobes and orbit indicate more advanced lesions ${ }^{14}$. Metastases usually occur as a late event and more commonly affect cervical lymph nodes ${ }^{15}$ as well as may also occur distant metastasis in sites such as in bones, liver and breasts ${ }^{13}$. Even so, in only about $5 \%$ of patients the cervical lymph nodes are affected. The patient of the case report had a tumor classified as Kadish $\mathrm{C}$ and Dugueirov T4, which are the most affected stages. However, there were no lymph nodes compromised and it was not possible to verify distant metastasis.

The gold standard diagnostic method is based on lesion biopsy, immunohistochemistry and ultrastructural findings ${ }^{1}$. The histopathological analysis of this tumor is based on the Hyams classification, which classifies low-grade (I and II) and highgrade (III and IV) ${ }^{11}$ samples, an important prognostic predictor of disease recurrence and survival rates ${ }^{16}$

Endoscopic or craniofacial excision are described as the treatment of choice, and may be associated with radiotherapy and chemotherapy, especially in more advanced stages of the 
disease $^{12}$. Most authors argue that Kadish A and B stages can be approached with endoscopic surgical therapy for tumor resection, while stages $\mathrm{C}$ and $\mathrm{D}$ require open craniofacial surgery ${ }^{17}$. Although esthesioneuroblastoma is a chemosensitive tumor, QT is only useful when combined with surgery and radiotherapy in patients with advanced tumors, local recurrence, metastasis or inoperable lesions. Survival rate has improved significantly after the introduction of chemotherapy into treatment, as it reduces the likelihood of local recurrence and distant metastasis, conditions that can arise even after years of treatment ${ }^{2}$. Some cases present good response to chemotherapy, mainly platinum-derivative chemoterapy ${ }^{18}$, as performed in the initial treatment of the case patient.

\section{CONCLUSIONS}

Esthesioneuroblastoma is a rare neoplasm and has a very unspecific clinical picture, especially in its early stages, which makes early diagnosis difficult. However, it is a tumor with aggressive biological behavior and the delay in recognition and start of treatment imply in a significant worsening of its prognosis. It is important to maintain a long-term monitoring even after the completion of treatment, in view of the high recurrence rate.

\section{REFERENCES}

1. Soares MZ, Chagas BF, Soares HBZ, Peron CS \& de Andrade Soares AC. Apresentação de neuroblastoma ectópico: relato de caso. Fag Journal Of Health (Fjh) 2019; $1(4), 107-111$.

2. Pérez AE, Hernández RCT \& Morales YV. Olfactory neuroblastoma. Cuban Journal of Otolaryngology and Head and Neck Surgery, 2019; 3(1).

3. Svane-Knudsen V, Jørgensen KE, Hansen O, Lindgren A \& Marker P. Cancer of the nasal cavity and paranasal sinuses: a series of 115 patients. Rhinology, 1998, 36(1), 12-14. 
4. Grau C, Jakobsen MH, Harbo G, Svane-Knudsen V, Wedervang K, Larsen SK \& Rytter C. Sino-nasal Cancer in Denmark 1982-1999-A Nationwide Survey. Acta Oncologica, 2001, 40(1), 19-23.

5. Granham DI, Lantos PL. Embrional tumors: olfactory neuroblastoma. In: Greenfield's neuropathology. 7th ed. London: John Wiley \& Sons; 2002. 2:879-82

6. Arauz D \& López R. Olfactory Esthesioneuroblastoma: A Case Presentation. Medical Journal of Panama, 2019; ISSN 2412-642X, 39(02).

7. Broich G, Pagliari A \& Ottaviani F. Since the Discovery of the Tumour in 1924. Anticancer Research, 1997, 17(26832706), 2683-2706.

8. Kadish S, Goodman M \& Wang CC. Olfactory neuroblastoma-a clinical analysis of 17 cases. Cancer, 1976, 37(3), 1571-1576.

9. Instituto Nacional de Câncer (INCA). TNM: classificação dos tumores malignos. Ministério da Saúde, Brasil 2004, 6a. ed. Rio de Janeiro 2004

10. Dulguerov P, Allal AS \& Calcaterra TC. Esthesioneuroblastoma: a meta-analysis and review. The Lancet oncology 2001, 2(11), 683-690.

11. Hyams VJ, Batsakis JG \& Michaels L. Tumors of the upper respiratory tract and ear. Armed Forces Institute of Pathology 1988.

12. Biller HF, Lawson W, Sachdev VP \& Som P. Esthesioneuroblastoma: surgical treatment without radiation. The Laryngoscope 1990, 100(11), 1199-1201.

13. Ferreira MCF, Tonoli C, Varoni ACC, Gusmon CC, Alvarenga M, Chagas JF and Pascoal MBN. Esthesioneuroblastoma. Revista de Ciências Médicas Campinas, 2007, 16, 193-198. 
14. Tamase A, Nakada M., Hasegawa M, Shima H \& Yamashita J. Recurrent intracranial esthesioneuroblastoma outside the initial field of radiation with progressive dural and intraorbital invasion. Acta neurochirurgica, 2004, 146(2), 179-182.

15. Rinaldo A, Ferlito A, Shaha AR, Wei WI \& Lund VJ. Esthesioneuroblastoma and cervical lymph node metastases: clinical and therapeutic implications. Acta oto-laryngologica 2002, 122(2), 215-221.

16. Valenzuela R, Ginsberg L, Shatzkes D, Michel M, Loevner L, Hanna E, ... \& Riascos R. Metástasis durales: una forma infrecuente de recurrencia en tumores nasosinusales malignos. Revista chilena de radiología 2016, 22(4), 164-170.

17. Cecenarro LA, Rodrigo Fantón ET, Estario P, Mezzano E, Berra MS, Olocco RV, ... \& Estario, ME. Secreción ectópica de ACTH: Presentación infrecuente de un estesioneuroblastoma. Rev. argent. endocrinol. metab 2014, 192-196.

18. De Vos FY, Willemse PHB \& de Vries, EGE. Successful treatment of metastatic esthesioneuroblastoma. Neth J Med 2003, 61(12), 414-416. 